\title{
PEMBELAJARAN BERBASIS STEM MATERI ELEKTROPLATING MENINGKATKAN PEMAHAMAN KONSEP DAN KETERAMPILAN BERFIKIR KRITIS SISWA
}

\author{
Eny Triastuti \\ SMA Negeri 1 Yogyakarta \\ email: teni50@yahoo.co.id
}

\begin{abstract}
ABSTRAK
Tujuan dari penelitian ini adalah untuk mendeskripsikan dan mengetahui pengaruh pembelajaran berbasis STEM pada materi pokok elektroplating terhadap pemahaman konsep dan keterampilan berfikir kritis siswa. Penelitian pendahuluan menemukan bahwa pembelajaran yang digunakan di SMA Negeri 1 Yogyakarta belum berorientasi pada keterampilan abad ke-21 yaitu melatihkan keterampilan berpikir kritis, kreatif, kerjasama, dan komunikasi. Siswa dipersiapkan tidak hanya untuk melanjutkan pendidikan ke jenjang yang lebih tinggi, tetapi harus bisa menyelesaikan tantangan dan masalah-masalah yang dihadapi dalam kehidupan sehari-hari. Penelitian ini adalah penelitian pre-Experimen Design dengan metode One-Group Pretest Posttest Design menurut Sugiyono (2018:74). Desain penelitian ini adalah One-Group Pretest-Posttest Design yaitu diberi perlakuan pretest sebelum diberi perlakuan agar hasil perlakuan dapat diketahui. Uji validitas isi (content validity) untuk instrumen penelitian berupa angket variabel diperoleh melalui pendapat ahli (expert judgment) yaitu pakar ahli dari Widya Iswara PPPPTK IPA sebagai pakar ahli model pembelajaran dan materi instrumen untuk menelaah instrumen penilaian berfikir kritis siswa. Implementasi pembelajaran berbasis STEM pada materi pokok elektroplating dapat disimpulkan bahwa Model Pembelajaran STEM PJBL pada topik materi electroplating dapat meningkatan keterampilan berfikir kritis siswa melalui lima tahapan belajar yaitu refleksion, reseach, discovery, aplication, dan communication serta meningkatkan pemahaman konsep siswa dengan nilai rata-rata pre-posttest 61,19 menjadi 90 dengan skor $\mathrm{N}$ gain sebesar 0,74 dengan kategori tinggi. Hasil penelitian menunjukkan adanya pengaruh positif pembelajaran berbasis STEM materi elektroplating terhadap keterampilan berfikir kritis dengan skor nilai 2,66 dari rentang 1-3 atau 88,50 .
\end{abstract}

Kata Kunci: STEM, elektroplating, berfikir kritis

\section{PENDAHULUAN}

Kuriukulum 2013 menyatakan bahwa salah satu pola pikir baru yang digunakan sebagai dasar pengembangan Kurikulum 2013 adalah pergeseran pola pembelajaran ilmu pengetahuan tunggal (monodiscipline) menjadi pembelajaran ilmu pengetahuan jamak (multidiscipline). Hal ini mengisyaratkan bahwa Kurikulum 2013 memberikan ruang bagi pengembangan dan implementasi 
pendidikan modern seperti pendekatan pendidikan berbasis STEM (Science, Technology, Engineering, and Mathemeatics). Untuk menyiapkan peserta didik Indonesia memperoleh keterampilan abad 21 (Dir PSMK, 2017), yaitu dengan melatih keterampilan cara berpikir melalui berpikir kritis, kreatif, mampu memecahkan masalah dan mengambil keputusan serta cara bekerja sama melalui kolaborasi dan komunikasi. Pendekatan STEM diadopsi untuk menguatkan impelementasi Kurikulum Nasional (Kurikulum 2013). Pendekatan STEM diyakini sejalan dengan ruh Kurikulum 2013 yang dapat diimplementasikan melalui penggunaan model pembelajaran berbasis proyek (PJBL) dengan menggunakan scientific dan engineering practices.

Banyak topik materi dalam mata pelajaran Kimia yang dapat digunakan sebagai titik awal pembelajaran berbasis STEM. Implementasi pembelajaran berbasis STEM materi pokok Elektroplating telah digunakan sebagai tema sentral proses KBM terintegrasi dengan mata pelajaran lain seperti Fisika dan Matematika serta desain enjiniring dan technologi terapan. Elektroplating atau penyepuhan logan dijadikan tema utama di mana siswa diminta untuk mendesain rangkaian elektroplating atau penyepuhan logam hingga menguji coba desain dan mengkalkulasi biaya produksi.

Unit pembelajaran berbasis STEM (Devi et al., 2018) dengan judul Elektroplating yang sudah disusun oleh tim pengembang SEAQIS dan P4TK IPA yang berisi pedoman untuk guru dalam menyajikan pembelajaran topik tentang stoikiometri reaksi redoks dan hukum Faraday untuk menghitung besaran-besaran yang terkait sel elektrolisis sudah diimplementasikan di SMA Negeri 1 Yogyakarta. Sekolah ini sangat cocok untuk dilaksanakan pembelajaran dengan model STEM PJBL, yaitu pembelajaran yang dirancang dengan menggunakan pendekatan STEM: science, technology, engineering, and mathematics. Melalui pembelajaran dengan pendekatan STEM, peserta didik belajar tentang sains, teknologi, teknik dan matematika untuk menjadi pemecah masalah, inovator, pencipta, dan kolaborator dan terus mengisi jalur kritis insinyur, ilmuwan, dan inovator yang sangat penting bagi masa depan. 
Berdasarkan latar belakang masalah diatas maka dapat disusun perumusan masalah yaitu 1) Bagaimanakah deskripsi implementasi pembelajaran berbasis STEM materi pokok elektroplating di SMA Negeri 1 Yogyakarta? 2) Bagaimana pengaruh Pembelajaran Berbasis STEM Pada Materi Pokok Elektrolisis terhadap Pemahaman Konsep siswa? 3) Bagaimana pengaruh Pembelajaran Berbasis STEM Pada Materi Pokok Elektroplating terhadap Keterampilan Berfikir Kritis siswa? Adapun tujuan penelitian yang dilakukan adalah: 1) Mendeskripsikan implementasi pembelajaran berbasis STEM materi pokok elektroplating di SMA Negeri 1 Yogyakarta. 2) Mengetahui pengaruh Pembelajaran Berbasis STEM Pada Materi Pokok Elektrolisis terhadap pemahaman konsep siswa. 3) Bagaimana pengaruh pembelajaran berbasis STEM Pada Materi Pokok Elektrolisis terhadap keterampilan berfikir Kritis.

Menurut Bybee (Byebee, 2013) yang dikenal dengan Model 5E bahwa tuntutan untuk karier yang sukses di abad 21 benar-benar berbeda dari pada abad ke-20. Dengan kemajuan teknologi yang selalu berubah dan masalah baru yang muncul, kita harus mempersiapkan siswa untuk pekerjaan dan tantangan yang mungkin bahkan tidak ada untuk saat ini. Siswa harus dilengkapi dengan keterampilan pemecahan masalah yang memungkinkan mereka untuk secara sistematis mencari solusi dari masalah yang mereka hadapi. Selain itu, Internet telah membuat informasi mudah dan cepat diakses, yang telah menyebabkan pergeseran dari kebutuhan untuk menghafal menjadi belajar bagaimana memperoleh informasi yang valid dan membuat informasi baru berdasarkan hasil pengamatan dan analisis. Mesin juga telah mengurangi kebutuhan akan tenaga kerja yang tidak terampil, sehingga penting bagi siswa kami untuk mengetahui bagaimana menerapkan konsep daripada hanya memahami konsep. Tuntutan baru ini adalah alasan proses rekayasa, Project-Based Learning (PJBL), dan Design Process sekarang menjadi fokus dalam kurikulum abad 21.

Engineering Design Process adalah pendekatan sistematis ketika mengembangkan solusi untuk menyelesaikan masalah dengan hasil yang jelas (well defined outcome). Mengikuti struktur design process yang baik sangat penting karena akan menghasilkan solusi terbaik, serta dapat membangun 
kemampuan dan logika pemecahan masalah. Salah satu sumber lain Engineering design dapat direpresentasikan oleh 7 tahap yaitu sebagai berikut: Identify Problem and Constraints; Research; Ideate; Analyze Ideas; Build; Test and Refine; Communicate and Reflect.

Elektroplating adalah aplikasi dari proses elektrolisis, dibuat dengan jalan mengalirkan arus listrik melalui larutan antara logam atau material lain yang konduktif. Dua buah plat logam merupakan anoda dan katoda dihubungkan pada kutub positif dan negatif terminal sumber arus searah (DC). Logam yang terhubung dengan kutub positif disebut anoda dan yang terhubung dengan kutub negatif disebut katoda. Ketika sumber tegangan digunakan pada elektrolit, maka kutub positif mengeluarkan ion bergerak dalam larutan menuju katoda dan disebut sebagai kation. Kutub negatif juga mengeluarkan ion, bergerak menujuanoda dan disebut sebagai anion. Hubungan antara voltase dalam elektrolit dan kekuatan arus listrik yang mengalir ditunjukkan oleh hukum Ohm yaitu besarnya listrik yang mengalir yang dinyatakan dengan Coulomb adalah sama dengan arus listrik dikalikan dengan waktu.

Landasan pustaka hukum Faraday ini adalah Hukum I yaitu jumlah dari tiap elemen atau grup dari elemen-elemen yang dibebaskan pada kedua anoda dan katoda selama elektrolisa sebanding dengan jumlah listrik yang mengalir dalam larutan. Selanjutnya Hukum II yang menjelaskan bahwa jumlah dari arus listrik bebas sama dengan jumlah ion atau jumlah substansi ion yang dibebaskan dengan memberikan sejumlah arus listrik adalah sebanding dengan berat ekivalennya.

Pembelajaran Elektroplating dengan pendekatan STEM dalam unit ini dirancang dengan menggunakan model STEM Project Based Learning (Capraro et al., 2013). Karakteristik utama dalam rancangan pembelajaran dengan pendekatan STEM ini adalah adanya scientific dan engineering practices yang dibelajarkan kepada peserta didik serta crosscutting concept yang menjadi jembatan yang menghubungkan antara sains yang dipelajari dengan teknologi serta engineering. Keterampilan abad 21 yang dikembangkan melalui pembelajaran elektroplating dengan pendekatan STEM meliputi berpikir kritis dan kreatif untuk melatih kemampuan memecahkan masalah yang erat kaitannya dalam kehidupan sehari-hari. 
Manfaat yang diharapkan dari penelitian ini bagi sekolah untuk melakukan rintisan pembelajaran berbasis STEM dan STEM School yang melibatkan kerjasama antara guru lintas mata pelajaran, bagi guru memberi gambaran bahwa implementasi Kurikulum 2013 dapat dilakukan dengan melatih siswa memiliki keterampilan yang diperlukan abad 21 yaitu berfikir kritis, kreatif, kerjasama dan komunikasi dan bagi siswa adalah mendapatkan pengalaman belajar serta bekal kompetensi soft skills yang diperlukan untuk memecahkan masalah dalam kehidupan nyata sehari-hari.

\section{METODE}

Penelitian ini merupakan bentuk pre-Experimental Design. Sugiyono (Sugiyono, 2019), menyatakan pre-Experimen desain ini belum merupakan eksperimen sungguh-sungguh karena masih terdapat variable luar yang ikut berpengaruh terhadap terbentuknya variable dependen. Hasil eksperimen yang merupakan variabel bukan semata-mata dipengaruhi oleh variabel independen. Hal ini karena tidak adanya variabel kontrol, dan sampel tidak dipilih secara random. Bentuk desain penelitian ini adalah One-Group Pretest-Posttest Design yaitu diberi perlakuan pretest sebelum diberi perlakuan agar hasil perlakuan dapat diketahui lebih akurat. Keadaan sebelum diberi perlakuan dapat dibandingkan dengan keadaan setelah diberi perlakuan. Desain ini dapat digambarkan sebagai berikut

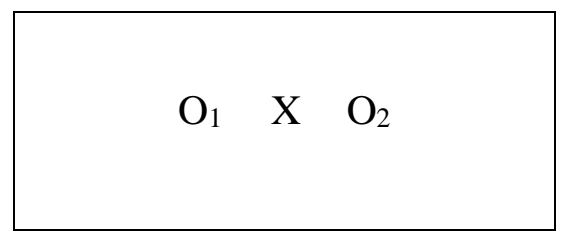

\section{Gambar 1. Desain penelitian menurut Sugiyono}

Keterangan ;

$\mathrm{O}_{1} \quad=$ nilai pretest sebelum diberi perlakuan pembelajaran STEM

$\mathrm{O}_{2}=$ nilai posttest sesudah diberi perlakuan pembelajaran STEM

$\mathrm{O}_{2}-\mathrm{O}_{1}=$ Pengaruh pembelajaran STEM terhadap kemampuan pemahaman konsep 
Waktu pelaksanaan penelitian adalah pada semester ganjil tahun ajaran 2018/2019 bertempat di SMA Negeri 1 Yogyakarta. Subjek penelitian ini adalah siswa kelas XII program MIPA SMA Negeri 1 Yogyakarta pada tahun ajaran 2018/2019. Pengambilan sampel tidak dipilih secara random, telah ditentukan yaitu semua siswa kelas XII MIPA 1 yang berjumlah 27 siswa. Dalam penelitian ini terdapat satu variabel bebas dan empat variabel terikat yang berdiri sendirisendiri untuk memberikan gambaran data dan informasi yang diperlukan untuk menyelesaikan masalah penelitian. Variabel bebas $(\mathrm{X})$ adalah pembelajaran STEM sedangkan empat variael terikat adalah hasil belajar sebagai pemahaman konsep siswa, penilaian keterampilan berfikir kritis, keterampilan kerjasama, dan komunikasi. Variabel penelitian terdiri dari 2 (dua) variabel yang berdiri sendirisendiri, karena tidak adanya kelas control maka dalam dalam ini ada 2 instrumen yaitu instrumen untuk mengukur pemahaman konsep atau hasil belajar dan instrumen untuk mengukur keterampilan berfikir kritis.

Uji validitas isi (content validity) yang digunakan untuk instrumen penelitian berupa angket variabel pada variabel $\mathrm{X}$ melalui pendapat ahli (expert judgment), peneliti meminta bantuan kepada pakar ahli dari Widya Iswara PPPPTK IPA sebagai pakar ahli model pembelajaran dan materi instrumen yang berkaitan untuk menelaah instrumen mengenai keterampilan abad 21 (4C) yaitu instrumen penilaian berfikir kritis siswa.

Langkah-langkah kegiatan dalam penelitian ini meliputi 3 tahapan yaitu tahap persiapan, pelaksanaan, dan pelaporan. Tapap persiapan meliputi observasi sekolah sebagai lokasi penelitian, studi literature mengenai materi yang menjadi topik penelitian, menetapkan kompetensi dasar (Permendikbud No. 24 Tahun 2016 Tentang Kompetensi Inti Dan Kompetensi Dasar Pelajaran Pada Kurikulum 2013 Pada Pendidikan Dasar Dan Pendidikan Menengah, 2016) yang akan dijadikan topik penelitian, menyusun rencana pelaksanaan pembelajaran (RPP), dan menyiapkan bahan ajar.

Kegiatan pada tahap pelaksanaan peneliti terjun langsung ke lapangan tempat penelitian dan melakukan antara lain nmngambil sampel yaitu kelas XII MIPA 1, memberi pretest, melaksanaan pembelajaran menggunakan skenario atau 
rancangan pembelajaran STEM pada topik elektroplating. Pembelajaran dilaksanakan dalam dua kali pertemuan dengan alokasi waktu masing-masing pertemuan 2 x 45 menit masing-masing dengan pretest - posttest. Tahap pelaporan yaitu menganalisis dan mengolah data hasil penelitian serta pelaporan hasil penelitian.

Instrument yang digunakan untuk mengumpulkan data adalah tes hasil belajar materi elektroplating berbentuk obyektif digunakan untuk mengetahui pemahaman konsep sebelum dan sesudah diberi perlakuan pembelajaran STEM atau pre-posttest. Sedangkan untuk mengukur nilai keterampilan dan sikap analisis data dilakukan secara deskriptif kuantitatif dengan skala Likert. Tahap mengumpulkan data ini dilaksanakan ketika peneliti melakukan pengumpulan data dengan alat pengumpul data yang sebelumnya telah ditentukan. Tahap tabulasi data yaitu mencatat atau entri data kedalam tabel induk penelitian. Desain penelitian ini adalah One-Group Pretest Posttest tanpa kelas kontrol sehingga tidak dilakukan analisa data secara statistik.

\section{HASIL DAN PEMBAHASAN}

Penelitian ini untuk mengetahui pengaruh pembelajaran berbasis STEM terhadap peningkatan pemahaman konsep dan keterampilan berfikir berpikir kritis siswa pada kelas eksperimen yang mendapatkan perlakuan pembelajaran berbasis STEM. Pembelajaran tatap muka untuk penelitian dilakukan sebanyak 4 (empat) kali pertemuan. Observasi lapangan untuk mengetahui aktivitas dan pengambilan nilai keterampilan dilakukan sebanyak 2 (dua) kali pertemuan yaitu pada hari Selasa dan Kamis ttanggal 25 dan 27 September 2018 di kelas XII MIPA 1 SMA Negeri Yogyakarta yang berjumlah 27 (dua puluh tujuh) siswa oleh observer. Observasi dilakukan untuk mengetahui dan mengukur keterampilan dan sikap siswa selama berlangsunya pembelajaran.

Kegiatan pembelajaran dalam penelitian ini dilaksanakan selama empat kali pertemuan dengan rincian kegiatan pada pertemuan pertama seluruh siswa diberikan tes awal (pretest) untuk mengetahui kemampuan awal pemahaman konsep siswa. Hasil pre test ternyata jauh dari KKM yang ditentukan standar 
kurikulum sekolah, rata- rata yang diperoleh adalah 61,19. Nilai ini sangat jauh dari kenyataan yang sebenarnya karena nilai input siswa di sekolah ini rata-rata di atas 90. Hal ini mungkin karena kondisi siswa yang masih lelah seusai mengikuti Penilaian Tengah Semester dan belum sempat belajar materi elektrolisis, apalagi type soalnya sangat HOTS dan realwords yang belum terbiasa diterima siswa. Harapan guru dengan materi pretest ini akan mendorong siswa untuk mencari tahu dan siap mempelajari electroplating dengan segenap potensinya. Butir soal yang diujikan terdapat dalam lampiran laporan penelitian ini

Pada pertemuan ke dua dan ke tiga yaitu 25 dan 27 September siswa kelas eksperimen mendapatkan perlakuan berupa pembelajaran berbasis STEM. Pada pertemuan kedua pembelajaran dilangsungkan di ruang kelas, dan pertemuan ketiga pembelajaran dilaksanakan di ruang laboratorium kimia. Sedangkan pada pertemuan terakhir seluruh siswa diberikan tes akhir (post-test) untuk dan angket respon untuk mengetahui respon kemampuan akhir berpikir kritis siswa.

Pada pertemuan kedua pembelajaran dilangsungkan di ruang kelas pada fase reflection, yaitu guru membimbing siswa untuk mengunggah kembali pengetahuannya tentang konsep elektrolisis dan peranannya dalam kehidupan. Dilanjutkan fase research yaitu guru mengarahkan siswa agar menggali informasi tentang peranan elektrolisis khususnya elektroplating dalam penyepuhan logam. Pada kegiatan inti fase discovery ini siswa secara berkelompok menyusun rancangan desain atau desain alat bahan penyepuhan logam yang efektif, efisian serta produktif, guru memberi batasan agar menggunakan logam terpilih serta produk yang dihasilkan memiliki ketebalan tertentu yang terukur. Contoh desain rancangan terlihat pada gambar 2 . 


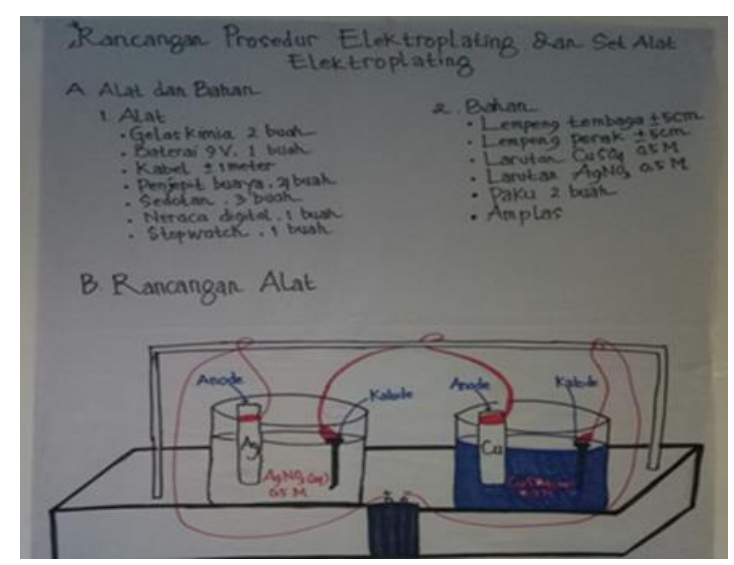

Gambar 2. Contoh rancangan / desain alat dan bahan yang dibuat siswa pada fase discocery (dokumen pribadi guru)

Pertemuan ketiga pembelajaran dilaksanakan di ruang laboratorium yaitu fase application, siswa menguji coba rancangannya dan ketika hasilnya tidak sesuai yang diharapkan maka harus dilakukan re-desain dan menguji coba kembali desain rancangan terbaru, disinilah kekhasan pembelajaran STEM yaitu adanya engenering desain process $(E D P)$. Kegiatan terakhir pada pertemuan ketiga adalah fase communication, siswa mempresentasikan hasil uji coba serta mereview hasil kegiatannya. Kegiatan pada fase ini adalah mengkalkulasi biaya serta mempresentasikan produknya dalam diskusi kelas, disinilah siswa dibangun karakter dan semangat kolaborasi. Produk coba yang dihasilkan dalam fase application dapat dilihat pada gambar 3 . 


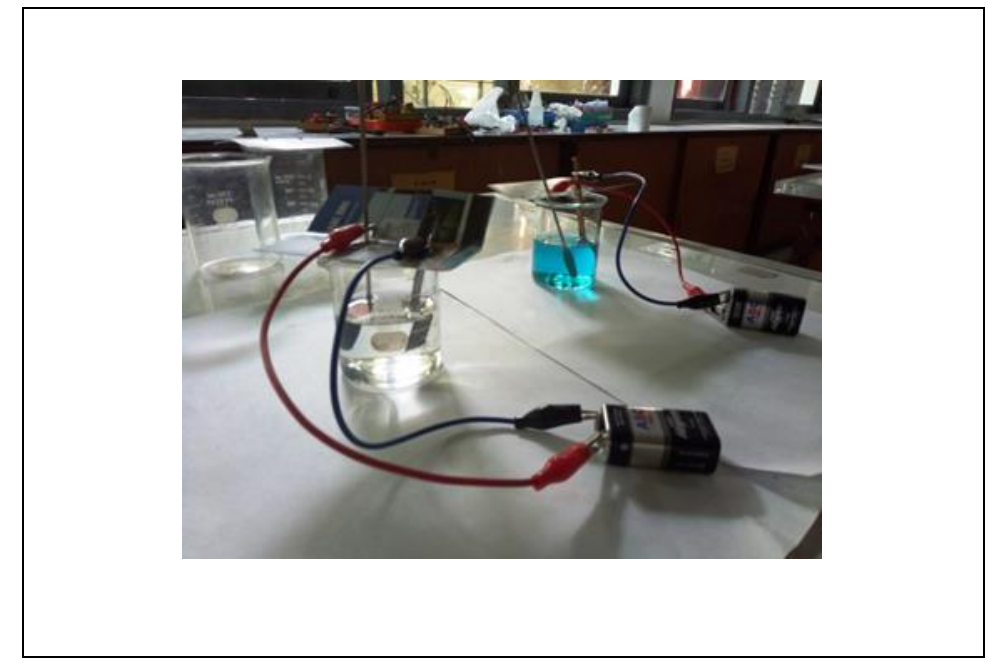

Gambar 3. Proses pengujian desain rancangan pada fase application disepakati pada fase Discovery. (dokumen pribadi guru)

Selama kegiatan kelas pembelajaran berbasis STEM peneliti dibantu observer melakukan pengamatan mengenai aktivitas siswa dan mencatatnya dengan instrument yaitu instrument keterampilan berfikir kritis, keterampilan komunikasi, dan kerja sama. Pertemuan kedua yaitu tanggal 25 September 2018 pembelajaran dengan kegiatan fase reflection, research, dan discovery. Pada fase pembelajaran ini siswa terbagi menjadi 6 kelompok dan semua kelompok telah berhasil membuat rancangan rekayasa desain proses dan prosedur elektroplating dan dipresentasikan dalam diskusi kelas. Pada akhir kegiatan telah disepakati model rekayasa rangkaian alat proses electroplating. Sedangkan pada tanggal 27 September kegiatan pembelajaran fase Application dan communication, yaitu tahap siswa melakukan uji coba hasil rancangan proses dan prosedur electroplating yang telah disepakati pada pertemuan sebelumnya. Pada kegiatan yang berlangsung di laboratorium ini guru terlebih dahulu memberikan arahan siswa memperhatikan keselamatan dan kesehatan akibat bahan kimia yang digunakan sangat berbahaya bagi kulit dan organ tubuh lainnya serta pembuangan limbah yang harus aman bagi lingkungan.

Semua siswa antusias dan berhasil menyelasaikan uji coba rancangan yang merupaka desain enginering proses yang menjadi karakteristik pembelajaran berbasis STEM. Pembelajaran diakhiri dengan presentasi kelompok dan review 
oleh guru bersama semua siswa. Aktivitas siswa dicatat oleh observer untuk memperoleh data nilai keterampilan dengan berpedoman pada instrument yang telah disusun dan divalidasi oleh pakar widya iswara PPPPTK IPA. Pada pertemuan ketiga dilakukan posttest dengan menggunakan butir soal yang sama pada pre test, hal ini untuk mengukur peningkatan pemahaman konsep siswa tentang materi elektrolisis terutama electroplating. Selanjutnya siswa melakukan self assessment dan penilaian antar teman untuk kegiatan dari fase reflection hingga communication.

Ketiga instrument Rubrik Penilaian yang digunakan untuk memperoleh data nilai keterampilan siswa selama pembelajaran terekam dan telah dicatat oleh observer. Penilaian sikap juga dilakukan pada pembelajaran berbasis STEM ini dan juga angket untuk mengetahui respon siswa terhadap pelaksanaan pembelajaran. Penilaian sikap meliputi self assessment, penilaian antar teman, dan jurnal yang dibuat oleh guru model bersama-sama observer.

Data yang diperoleh pada penelitian ini merupakan data penelitian eksperimen semu dengan satu variabel terikat yaitu pembelajaran berbais STEM dan dua variabel terikat yaitu kemampuan pemahaman konsep dan keterampilan berfikir kritis. Data utama yang dipakai untuk melihat pengaruh pembelajaran berbasis STEM terhadap peningkatan kemapuan pemahaman konsep adalah data hasil pretest dan posttest. Data tersebut dianalisis untuk melihat skor hasil tes. Selanjutnya hasil tes tersebut dihitung rataratanya. Serta menghitung N- Gain antara pretest dan posttest.

Dari data diperoleh bahwa telah terjadi peningkatan pemahaman konsep sebagaimana yang disajikan pada dari tabel 1 yaitu nilai pretest dengan rata-rata 61, 19 sedangakan nilai rata-rata posttest adalah 90, maka perolehan skor $\mathrm{N}$ gain adalah 0,74. Dengan demikian karena $\mathrm{g}>0,70$ yaitu sebesar 0,74 , dengan $\mathrm{N}$ gain sebesar itu maka berada pada kategori tinggi. Dengan demikian pembelajaran berbasis STEM sangat berpengaruh terhadap pemahaman konsep.

Data keterampilan berpikir kritis dikumpulkan dengan menggunakan instrument observasi sebelum pembelajaran dengan pendekatan STEM dan pada saat pembelajaran dengan pendekatan STEM pada subyek penelitian sesuai 
dengan fase pendekatan STEM meliputi; 1) reflection, 2) riseach, 3) discovery, 4) aplication, dan 5) comunication. Data hasil observasi berpikir kritis disajikan dalam bentuk tabel 1 dan grafik 1 .

Table 1. Nilai Hasil Berpikir Kritis sebelum dan sesudah Perlakuan

\begin{tabular}{ccc}
\hline Data & Skore Awal & Skore Akhir \\
& & \\
\hline Skor tertinggi & 73,33 & 98,33 \\
Skor terendah & 55,00 & 78,67 \\
Rata-rata & 64,17 & 88,50 \\
\hline
\end{tabular}

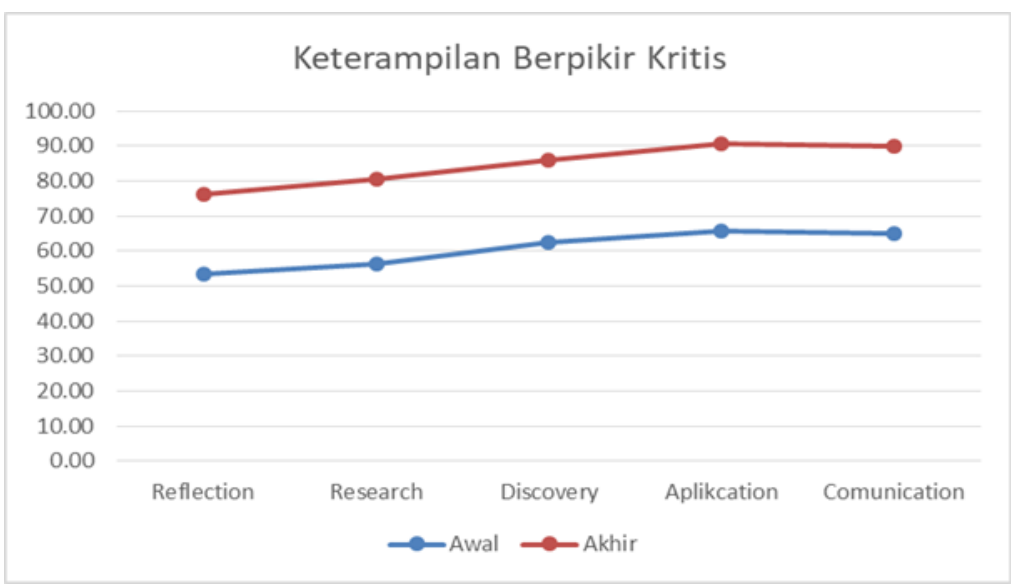

Grafik 1 Nilai Hasil Berpikir Kritis sebelum dan sesudah Perlakuan dengan Pendekatan STEM

Berdasarkan tabel dan grafik di atas nilai awal tertinggi 73,33, terendah 55,00 , dan rata-rata 64,17 sedangkan nilai akhir tertinggi 98,33, nilai terendah 78,67 , dan rata-rata 88,50 .

Secara keseluruhan nilai rata-rata pretest, post-test, dan N-gain kemampuan pemahaman konsep pada siswa kelas eksperimen telah mencapai standar. Demikian juga keterampilan berfikir kritis juga telah mencapai standar yaitu dengan rata-rata skor 2,66 dari rentang skor 1 - 3 atau sama dengan 88,50. Hanya ada 3 (tiga) dari 27 siswa yang memiliki nilai mendekati standar pada nilai keterampilan berfikir kritis dan keterampilan komunikasi. Sesuai dengan indikator dalam instrumen yang telah mendapat validasi dari pakar SEAQIS PPPPTK IPA 
(Indrawati, 2019) maka secara umum dinyatakan bahwa semua siswa dalam kelas eksperimen telah mencapai standar. Pada penilaian aspek sikap melalui self assessment diperoleh hasil bahwa hampir semua siswa menyatakan telah memahami konsep elektroplating secara benar. Hampir semua siswa juga telah melakukan kerjasama dengan teman di kelompoknya maupun dengan kelompok lain dalam berdiskusi dan menyelesaikan tugas proyek. Pada penilaian antar teman sebagian besar siswa dipandang memiliki integritas kedisiplinan, tenggang rasa, kerja sama dan menerima perbedaan pendapat. Sedangkan penilaian sikap di jurnal guru menyatakan bahwa semua siswa memiliki sikap sangat baik dan mampu melakukan pembelajaran sesuai dengan skenario rencana pembelajaran.

Berdasarkan pembahasan di atas dimengerti bahwa pembelajaran berbasis STEM telah terbukti mengambil peran dalam rangka mencapai tujuan pendidikan nasional dan perkembangan jaman, dan menuntut keterampilan berpikir kritis oleh karena itu akan menumbuhkan kreativitas siswa . Siswa dipersiapkan tidak hanya untuk melanjutkan pendidikan ke jenjang yang lebih tinggi, tetapi juga menyelesaikan tantangan dan masalah-masalah yang dihadapinya dalam kehidupan sehari-hari untuk menyambut abad 21.

\section{SIMPULAN}

Berdasarkan pembahasan analisis data pada penelitin ini maka dapat dipeoleh simpulan yaitu bahwa Pembelajaran berbasis STEM pada topik materi elektroplating dapat meningkatan keterampilan berfikir kreatif dan wirausaha siswa melalui lima tahapan belajar yaitu refleksion, reseach, discovery, aplication, dan communication. Pembelajaran Berbasis STEM pada materi pokok elektroolating dapat meningkatkan pemahaman konsep siswa dengan nilai preposttest 61,19 menjadi 90 dengan skor $\mathrm{N}$ gain sebesar 0,74 dengan kategori tinggi dan meningkatan keterampilan berfikir kreatif ditunjukkan oleh perolehan nilai rata-rata dari data observer sebesar 2,66 atau 88,5.

Berdasarkan kesimpulan di atas maka diberikan saran kepada pihak-pihak terkait agar pembelajaran berbasis STEM dapat dijadikan salah satu alternatif bagi guru untuk menambah variasi pendekatan pembelajaran dalam meningkatkan 
pemahaman konsep dan dapat meningkatkan keterampilan yang dibutuhkan abad 21 yaitu keterampilan berfikir kritis, keterampilan komunikasi, dan kemampuan kerja sama siswa. Dengan begitu guru dapat mengembangkan pola pikir siswa dengan menggunakan model STEM PJBL pada materi lain.

\section{DAFTAR PUSTAKA}

Byebee, R. W. (2013). Translating the NGSS for Classroom Instruction. In National Science Teacher Assosiation Press. https://doi.org/10.2505/9781938946011

Capraro, R. M., Capraro, M. M., \& Morgan, J. R. (2013). STEM project-based learning an integrated science, technology, engineering, and mathematics (STEM) approach. In Sense Publishers (Issue September). https://doi.org/10.1007/978-94-6209-143-6

Devi, P. K., Karyana, S., \& Nulhakim, L. (2018). Unit Pembelajaran STEM Mata Pelajaran kimia SMA Kelas XII. SEAMEO Regional Center for QITEP in Science.

Dir PSMK. (2017). Panduan Implementasi Kecakapan Abad 21 Kurikulum 2013 di SMA. In Direktorat Pembinaan Sekolah Menengah Atas.

Indrawati. (2019). Panduan SEAQIS Research Grants. 1, 105-112.

Permendikbud No. 24 Tahun 2016 Tentang Kompetensi Inti dan Kompetensi Dasar Pelajaran Pada Kurikulum 2013 Pada Pendidikan Dasar dan Pendidikan Menengah, (2016).

Sugiyono. (2019). Metode Penelitian Kuantitatif, Kualitatif, dan R\&D. Alfabeta. 